\title{
The role of calcium influx pathways in phospholipase $D$ activation in bovine adrenal glomerulosa cells
}

\author{
Haixia Qin ${ }^{2}$, Patricia Kent ${ }^{2}$, Carlos M Isales ${ }^{2,4}$, Peter M Parker ${ }^{2}$, Mariya V Wilson ${ }^{2}$ \\ and Wendy B Bollag ${ }^{1,2,3,4}$ \\ ${ }^{1}$ Charlie Norwood VA Medical Center, One Freedom Way, Augusta, Georgia 30904, USA \\ ${ }^{2}$ Institute of Molecular Medicine and Genetics, ${ }^{3}$ Departments of Medicine and Cell Biology and Anatomy and ${ }^{4}$ Department of Orthopaedic Surgery, Medical \\ College of Georgia, 1120 15th Street, Augusta, Georgia 30912, USA \\ (Correspondence should be addressed to W B Bollag; Email: wbollag@mcg.edu)
}

\begin{abstract}
The steroid hormone aldosterone maintains sodium homeostasis and is therefore important in the control of blood volume and pressure. Angiotensin II (AngII) and elevated extracellular potassium concentrations $\left(\left[\mathrm{K}^{+}\right]_{\mathrm{e}}\right)$, the prime physiologic regulators of aldosterone secretion from adrenal glomerulosa cells, activate phospholipase D (PLD) in these cells. The role of $\mathrm{Ca}^{2+}$ in the activation by these agents is unknown, although nitrendipine, a voltage-dependent $\mathrm{Ca}^{2+}$ channel antagonist, does not inhibit AngII-elicited PLD activation, despite the fact that this compound blocked elevated $\left[\mathrm{K}^{+}\right]_{\mathrm{e}}$-stimulated PLD activity. PLD activation triggered by AngII was also unaffected by the T-type calcium channel inhibitor nickel. Nevertheless, $\mathrm{Ca}^{2+}$ influx was required for AngII-induced PLD activation in both primary cultures of bovine adrenal glomerulosa cells and a glomerulosa cell model, the NCI H295R adrenocortical
\end{abstract}

carcinoma cell line. The involvement of store-operated $\mathrm{Ca}^{2+}$ (SOC) influx and $\mathrm{Ca}^{2+}$ release-activated $\mathrm{Ca}^{2+}$ (CRAC) influx pathways in PLD activation was investigated using thapsigargin, an endoplasmic reticulum $\mathrm{Ca}^{2+}$ pump inhibitor that empties the store to induce SOC influx, and the SOC inhibitor YM-58483 (BTP2), as well as a CRAC inhibitor, tyrphostin A9. In bovine glomerulosa cells, tyrphostin A9 inhibited AngII-induced PLD activation without affecting elevated $\left[\mathrm{K}^{+}\right]_{\mathrm{e}}$-stimulated enzyme activity. On the other hand, differences were observed between the bovine adrenal glomerulosa and H295R cells in the involvement of $\mathrm{Ca}^{2+}$ influx pathways in PLD activation, with the involvement of the SOC pathway suggested in the H295R cells. In summary, our results indicate that $\mathrm{Ca}^{2+}$ entry only through certain $\mathrm{Ca}^{2+}$ influx pathways is linked to PLD activation.

Journal of Endocrinology (2009) 202, 77-86

\section{Introduction}

The steroid hormone aldosterone controls sodium homeostasis and thus blood volume and pressure. Aldosterone is secreted from glomerulosa cells in the adrenal cortex in response to two major regulators, angiotensin II (AngII) and elevated extracellular potassium concentration $\left(\left[\mathrm{K}^{+}\right]_{\mathrm{e}}\right)$. AngII induces aldosterone secretion by binding to the AngII type 1 receptor, which is coupled to phosphatidylinositol 4,5-bisphosphate hydrolysis resulting in the production of inositol 1,4,5-trisphosphate and diacylglycerol (DAG; reviewed in Barrett et al. (1989), Foster (2004), Spät \& Hunyady (2004) and Rainey et al. (2008)). These second messengers, in turn, increase cytosolic calcium $\left(\mathrm{Ca}^{2+}\right)$ levels (to activate $\mathrm{Ca}^{2+} /$ calmodulin-dependent protein kinases) and stimulate protein kinase $\mathrm{C}$ (PKC) respectively (reviewed in Rainey et al. (2008)). Elevated $\left[\mathrm{K}^{+}\right]_{\mathrm{e}}$, on the other hand, triggers glomerulosa cell depolarization, which opens voltage-dependent $\mathrm{Ca}^{2+}$ channels and also increases cytosolic
$\mathrm{Ca}^{2+}$ levels (reviewed in Rainey et al. (2008)). We previously showed that not only AngII but also elevated $\left[\mathrm{K}^{+}\right]_{\mathrm{e}}$ activates phospholipase D (PLD; Betancourt-Calle et al. 2001), the activity of which can produce lipid messengers including phosphatidic acid and DAG (reviewed in Bollag \& Zheng (2005)). Furthermore, inhibition of PLD-mediated signal generation inhibits both AngII- and elevated $\left[\mathrm{K}^{+}\right]_{\mathrm{e}}$-elicited aldosterone secretion (Betancourt-Calle et al. 2001, Bollag et al. 2002, Zheng \& Bollag 2003), suggesting the importance of this signaling enzyme to steroid hormone production. Therefore, it is important to understand the mechanisms that regulate PLD activity in response to AngII and elevated $\left[\mathrm{K}^{+}\right]_{\mathrm{e}}$.

The ability of both AngII and elevated $\left[\mathrm{K}^{+}\right]_{\mathrm{e}}$ to activate PLD suggests a possible involvement of $\mathrm{Ca}^{2+}$ in the process, since an increase in the cytosolic $\mathrm{Ca}^{2+}$ concentration is common to these two agonists (reviewed in Rainey et al. (2008)). However, the role of $\mathrm{Ca}^{2+}$ in PLD activation in other systems is unclear, and, in fact, Exton (1999) indicated that 'direct control of the enzyme by physiological changes 
in cytosolic $\mathrm{Ca}^{2+}$ seems unlikely'. Investigators have shown an ability of cytosolic $\mathrm{Ca}^{2+}$ concentration to modulate PLD activity, with chelation of intracellular $\mathrm{Ca}^{2+}$ inhibiting PLD activation in response to some agonists and $\mathrm{Ca}^{2+}$ ionophores increasing enzyme activity (reviewed in Exton (1999)). The mechanism by which $\mathrm{Ca}^{2+}$ regulates PLD activity is not known but may involve calmodulin and/or the $\mathrm{Ca}^{2+}$-sensitive PKC isoenzymes (reviewed in Exton (1999)). On the other hand, in primary bovine glomerulosa cells, the inability of the $\mathrm{Ca}^{2+}$ ionophores ionomycin or A23187 to activate PLD (Bollag et al. 2002) suggests that changes in cytosolic $\mathrm{Ca}^{2+}$ levels alone are not sufficient to stimulate PLD activity. Furthermore, the fact that elevated $\left[\mathrm{K}^{+}\right]_{\mathrm{e}}$, which functions through voltage-dependent $\mathrm{Ca}^{2+}$ channels, activates PLD in bovine adrenal glomerulosa cells (Betancourt-Calle et al. 2001) suggests a possible involvement of $\mathrm{Ca}^{2+}$ influx in regulating PLD activity. However, the lack of inhibition of AngIIinduced PLD activation by nitrendipine (Bollag et al. 2002), a voltage-dependent $\mathrm{Ca}^{2+}$ channel antagonist, at a dose that inhibits aldosterone secretion (Kojima et al. 1985b), supports the idea that only certain $\mathrm{Ca}^{2+}$ pathways may be important in stimulating PLD in response to particular agonists.

The objectives of this study were to determine the role of $\mathrm{Ca}^{2+}$ influx pathways in activating PLD in response to AngII as well as to elevated $\left[\mathrm{K}^{+}\right]_{\mathrm{e}}$ in primary cultures of bovine adrenal glomerulosa cells. In addition, we sought to compare the effects of modulating $\mathrm{Ca}^{2+}$ influx on PLD activation and acute aldosterone secretion in this bovine system with the responses observed in the NCI H295R human adrenocortical carcinoma cell line.

\section{Materials and Methods}

\section{Materials}

The following were obtained from Sigma: phorbol 12-myristate 13-acetate (PMA), AngII, and 22(R)-hydroxycholesterol. UltroSer $G$ was acquired from BioSepra (Cergy St Christophe, France) under a permit from the US Department of Agriculture. $\left[{ }^{3} \mathrm{H}\right]$ Oleic acid was purchased from Dupont NEN (Boston, MA, USA). Silica gel 60 thin-layer chromatography plates with concentrating zones were obtained from EM Science through VWR (West Chester, PA, USA) and phosphatidylethanol (PEt) and phosphatidic acid standards from Avanti Polar Lipids (Alabaster, AL, USA). ITS + premix $(12.5 \mathrm{mg}$ insulin, $12.5 \mathrm{mg}$ transferrin, $12.5 \mu \mathrm{g}$ selenous acid, $10 \cdot 7 \mu \mathrm{g}$ linoleic acid, and $2.5 \mathrm{mg}$ BSA) was purchased from BD Biosciences (San Jose, CA, USA). Thapsigargin, YM-58483 (BTP2) and tyrphostin A9 were obtained from Calbiochem (San Diego, CA, USA).

\section{Primary culture of bovine adrenal glomerulosa cells}

Bovine adrenal glomerulosa cells were prepared and cultured as described in Bollag et al. (2007). Briefly, the glomerulosa layer was dissected from adrenal glands of near-term fetal calves obtained from a local meat-packing plant. Glomerulosa cells were released from tissue slices by enzymatic and mechanical means and collected by centrifugation. Cells were plated in Primaria plates (BD Falcon, Franklin Lakes, NJ, USA) overnight in a medium consisting of DMEM/Ham's F12 (1:1 vol:vol) containing 10\% horse serum, $2 \%$ fetal bovine serum, $100 \mu \mathrm{M}$ ascorbate, $1 \cdot 2 \mu \mathrm{M} \alpha$-tocopherol, $0 \cdot 05 \mu \mathrm{M}$ $\mathrm{Na}_{2} \mathrm{SeO}_{3}, 50 \mu \mathrm{M}$ butylated hydroxyanisole, $5 \mu \mathrm{M}$ metyrapone, $100 \mathrm{U} / \mathrm{ml}$ penicillin, $100 \mu \mathrm{g} / \mathrm{ml}$ streptomycin, and $0 \cdot 25 \mu \mathrm{g} / \mathrm{ml}$ fungizone. The cells were then incubated for 20-24 h in serum-free DMEM/Ham's F12 (containing $0 \cdot 2 \%$ BSA, $100 \mu \mathrm{M}$ ascorbate, $1 \cdot 2 \mu \mathrm{M} \alpha$-tocopherol, $0 \cdot 05 \mu \mathrm{M} \mathrm{Na}_{2} \mathrm{SeO}_{3}, 50 \mu \mathrm{M}$ butylated hydroxyanisole, $5 \mu \mathrm{M}$ metyrapone, and antibiotics) prior to experimentation.

\section{Culture of NCI H295R human adrenocortical carcinoma cells}

NCI H295R cells were cultured as described in Zheng \& Bollag (2003). Briefly, cells were grown in DMEM/Ham's F12 (1:1 vol:vol) containing $1 \%$ ITS $+(12.5 \mathrm{mg}$ insulin, $12.5 \mathrm{mg}$ transferrin, $12.5 \mu \mathrm{g}$ selenous acid, $10 \cdot 7 \mu \mathrm{g}$ linoleic acid, and $2 \cdot 5 \mathrm{mg}$ BSA from BD Biosciences), $2 \%$ UltroSer $\mathrm{G}$, $100 \mathrm{U} / \mathrm{ml}$ penicillin, $100 \mu \mathrm{g} / \mathrm{ml}$ streptomycin, and $0 \cdot 25 \mu \mathrm{g} / \mathrm{ml}$ fungizone, to $\sim 70-75 \%$ confluence. The cells were then incubated for 20-24 h in serum-free medium (consisting of DMEM/Ham's F12 containing $0 \cdot 01 \%$ BSA and antibiotics) prior to experimentation.

\section{Measurement of aldosterone secretion}

Cells were incubated for the indicated times with the appropriate agents in bicarbonate-buffered Kreb's Ringer containing $2.5 \mathrm{mM}$ sodium acetate $\left(\mathrm{KRB}^{+}\right)$. Aldosterone release into the medium was then assayed using a RIA kit from Diagnostic Products Corporation (Los Angeles, CA, USA) as described in Bollag et al. (2007). For stimulation with an elevated $\left[\mathrm{K}^{+}\right]_{\mathrm{e}}, \mathrm{KCl}$ was substituted iso-osmotically for $\mathrm{NaCl}$, as in Betancourt-Calle et al. (2001).

\section{PLD activity assay}

Bovine glomerulosa or H295R cells were prelabeled with $2 \cdot 5-5 \mu \mathrm{Ci} / \mathrm{ml}\left[{ }^{3} \mathrm{H}\right]$ oleate in the appropriate serum-free medium for 20-24 h. The cells were then preincubated for $30 \mathrm{~min}$ in $\mathrm{KRB}^{+}$prior to stimulation in the presence of $0 \cdot 5 \%$ ethanol with and without AngII in $\mathrm{KRB}^{+}$containing or lacking $1.2 \mathrm{mM} \mathrm{CaCl}_{2}$ or in the presence and absence of $50 \mu \mathrm{M} \mathrm{NiCl} 22 \mu \mathrm{M}$ thapsigargin or $10 \mu \mathrm{M}$ tyrphostin A9 (or DMSO as the vehicle control) for 5 (H295R cells) or $30 \mathrm{~min}$ (bovine adrenal glomerulosa cells). Again, stimulation with elevated $\left[\mathrm{K}^{+}\right]_{\mathrm{e}}$ was performed by iso-osmotic substitution. Phospholipids were extracted with chloroform/methanol and separated by thin-layer chromatography, and radiolabeled PEt was quantified by liquid scintillation spectrometry as described in Bollag (1998). 


\section{Statistical analysis}

Experiments were performed a minimum of three times in duplicate or triplicate. Data were analyzed by ANOVA with a Student-Newmann-Keuls post hoc test using the computer program Instat (Graphpad, San Diego, CA, USA), except where indicated in the figure legends. A $P$ value $\leq 0.05$ was considered significant.

\section{Results}

We have previously shown that elevated $\left[\mathrm{K}^{+}\right]_{\mathrm{e}}$ stimulates PLD activity (Betancourt-Calle et al. 2001). Because of the importance of PLD to sustained aldosterone secretion (Bollag et al. 2002, Zheng \& Bollag 2003), we wanted to characterize the mechanism by which elevated $\left[\mathrm{K}^{+}\right]_{\mathrm{e}}$ and AngII activate PLD. We previously showed that the voltage-dependent $\mathrm{Ca}^{2+}$ channel antagonist, nitrendipine, does not alter AngIIinduced PLD activation (Bollag et al. 2002), even at a concentration $(1 \mu \mathrm{M})$ reported to inhibit both transient, or T-type, and long-lasting, or L-type, $\mathrm{Ca}^{2+}$ channels (Barrett et al. 1995). The role of voltage-dependent $\mathrm{Ca}^{2+}$ channels in elevated $\left[\mathrm{K}^{+}\right]_{\mathrm{e}}$-induced PLD activation was determined by monitoring the effect of nitrendipine on the elevated $\left[\mathrm{K}^{+}\right]_{\mathrm{e}^{-}}$ stimulated increase in the levels of $\left[{ }^{3} \mathrm{H}\right] \mathrm{PEt}$, a specific marker of PLD activity (Thompson et al. 1991), in $\left[{ }^{3} \mathrm{H}\right]$ oleateprelabeled primary bovine adrenal glomerulosa cells (Bollag et al. 1990, 1992). Nitrendipine (1 $\mu \mathrm{M})$ completely abolished elevated $\left[\mathrm{K}^{+}\right]_{\mathrm{e}}$-induced changes in PLD activity (Fig. 1),

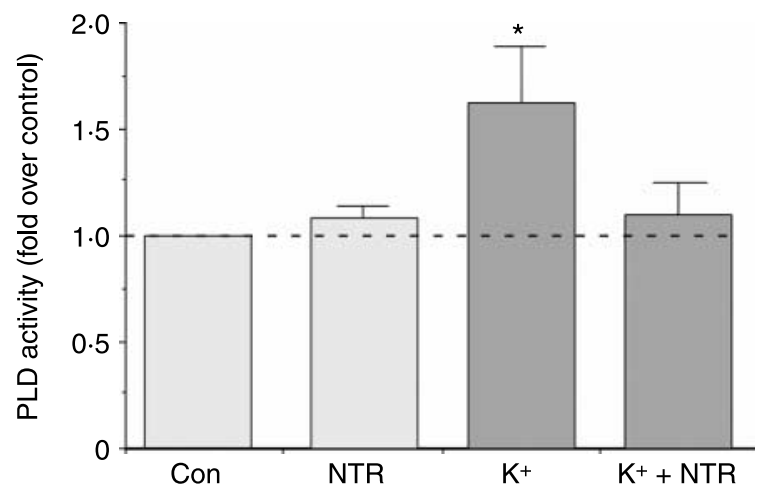

Figure 1 Inhibition of $\mathrm{Ca}^{2+}$ influx with nitrendipine completely inhibited elevated $\left[\mathrm{K}^{+}\right]_{\mathrm{e}}$-elicited PLD activation. $\left[{ }^{3} \mathrm{H}\right] \mathrm{Oleate}-$ prelabeled cells were incubated for $30 \mathrm{~min}$ with $\mathrm{KRB}^{+}$containing $3.5 \mathrm{mM} \mathrm{KCl}\left(3.5 \mathrm{mM} \mathrm{K}^{+}-\mathrm{KRB}^{+}\right.$, control), $1 \mu \mathrm{M}$ nitrendipine (NTR) in $3.5 \mathrm{mM} \mathrm{K}^{+}-\mathrm{KRB}^{+}, 15 \mathrm{mM} \mathrm{K}^{+}-\mathrm{KRB}^{+}$, or $1 \mu \mathrm{M} \mathrm{NTR}$ in $15 \mathrm{mM}$ $\mathrm{K}^{+}-\mathrm{KRB}^{+}$in the presence of $0.5 \%$ ethanol. (Note that $\mathrm{NaCl}$ in the medium was substituted for by $\mathrm{KCl}$ to maintain osmolarity in the $15 \mathrm{mM} \mathrm{K}^{+}-\mathrm{KRB}^{+}$as in Betancourt-Calle et al. (2001)). Reactions were terminated by the addition of $0 \cdot 2 \%$ SDS containing $5 \mathrm{mM}$ EDTA, and $\left[{ }^{3} \mathrm{H}\right]$ phosphatidylethanol was extracted, separated by thin-layer chromatography and quantified as in Jung et al. (1998). Values are expressed as -fold over the control and represent the means ( \pm S.E.M.) of five separate experiments; ${ }^{*} P<0.05$ versus the control value. although it had no effect on either basal (Fig. 1; Bollag et al. 2002) or AngII-stimulated PLD activity (Bollag et al. 2002), indicating that $\mathrm{Ca}^{2+}$ influx through voltage-dependent $\mathrm{Ca}^{2+}$ channels is absolutely required for the effect of elevated $\left[\mathrm{K}^{+}\right]_{\mathrm{e}}$ on PLD activity.

To further define the involvement of T-type versus L-type channels in the PLD response to AngII and elevated $\left[\mathrm{K}^{+}\right]_{\mathrm{e}}$, we used the T-type channel inhibitor, nickel, at a dose reported to inhibit T-type $\mathrm{Ca}^{2+}$ influx, specifically through $\alpha-1 \mathrm{H}$ T-type $\mathrm{Ca}^{2+}$ channels (Schrier et al. 2001). We observed no effect of $50 \mu \mathrm{M}$ nickel on PLD activity either under basal conditions or upon stimulation with AngII (Fig. 2A). On the other hand, elevated $\left[\mathrm{K}^{+}\right]_{\mathrm{e}}$-stimulated PLD activity, and nickel returned this increase to a level not significantly different from the control value, causing an approximate $43 \%$ inhibition (Fig. 2B). Together, these results are consistent with the idea that voltage-dependent $\mathrm{Ca}^{2+}$ channels are not involved in AngII-induced PLD activation but are critical for the activity stimulated by elevated $\left[\mathrm{K}^{+}\right]_{\mathrm{e}}$.

To determine whether $\mathrm{Ca}^{2+}$ influx was involved in AngII's activation of PLD, AngII-stimulated PLD activity was then examined in the presence or absence of extracellular $\mathrm{Ca}^{2+}$. Interestingly, we observed a reduction in radiolabeled PEt production in the absence of $\mathrm{Ca}^{2+}$ in primary bovine adrenal glomerulosa cells (Fig. 3). This result suggests that whereas elevated $\left[\mathrm{K}^{+}\right]_{\mathrm{e}}$ requires $\mathrm{Ca}^{2+}$ influx through voltagedependent $\mathrm{Ca}^{2+}$ channels, AngII-elicited PLD activation is independent of $\mathrm{Ca}^{2+}$ influx through voltage-dependent $\mathrm{Ca}^{2+}$ channels but nevertheless requires $\mathrm{Ca}^{2+}$ entry, presumably through store-operated $\mathrm{Ca}^{2+}(\mathrm{SOC})$ or $\mathrm{Ca}^{2+}$ release-activated $\mathrm{Ca}^{2+}$ (CRAC) channels.

To test the role of SOC influx in AngII- and elevated extracellular $\left[\mathrm{K}^{+}\right]_{\mathrm{e}}$-induced PLD activation, we determined the effects on PLD activity of thapsigargin, a pharmacologic agent that inhibits the sarcoplasmic/endoplasmic reticulum $\mathrm{Ca}^{2+}$ pump to release $\mathrm{Ca}^{2+}$ from these stores and activate SOC influx (reviewed in Spät \& Hunyady (2004)). We selected a dose of thapsigargin $(2 \mu \mathrm{M})$ that has previously been shown to increase SOC $\mathrm{Ca}^{2+}$ influx in primary cultures of bovine adrenal glomerulosa cells (Burnay et al. 1998, Aptel et al. 1999). We found that thapsigargin had little effect on AngII-induced PLD activation (Fig. 4A) in primary bovine adrenal glomerulosa cells, whereas this compound stimulated elevated $\left[\mathrm{K}^{+}\right]_{\mathrm{e}}$-elicited PLD activity (Fig. 4B). Interestingly, these results were mirrored by the effects of thapsigargin on aldosterone secretion in that the compound had little effect on AngII-induced steroidogenesis but augmented elevated $\left[\mathrm{K}^{+}\right]_{\mathrm{e}}$-elicited aldosterone secretion (Fig. 5A), consistent with a previous report in bovine adrenal glomerulosa cells (Burnay et al. 1994). In addition, thapsigargin enhanced the aldosterone secretory response to the phorbol ester, PMA, which mimics DAG action in primary bovine adrenal glomerulosa cells (Fig. 5B). This latter result is consistent with the proposed requirement for two signals mediating sustained aldosterone secretion: a DAG second messenger and a $\mathrm{Ca}^{2+}$ influx signaling pathway (reviewed in Rasmussen et al. (1995)). 

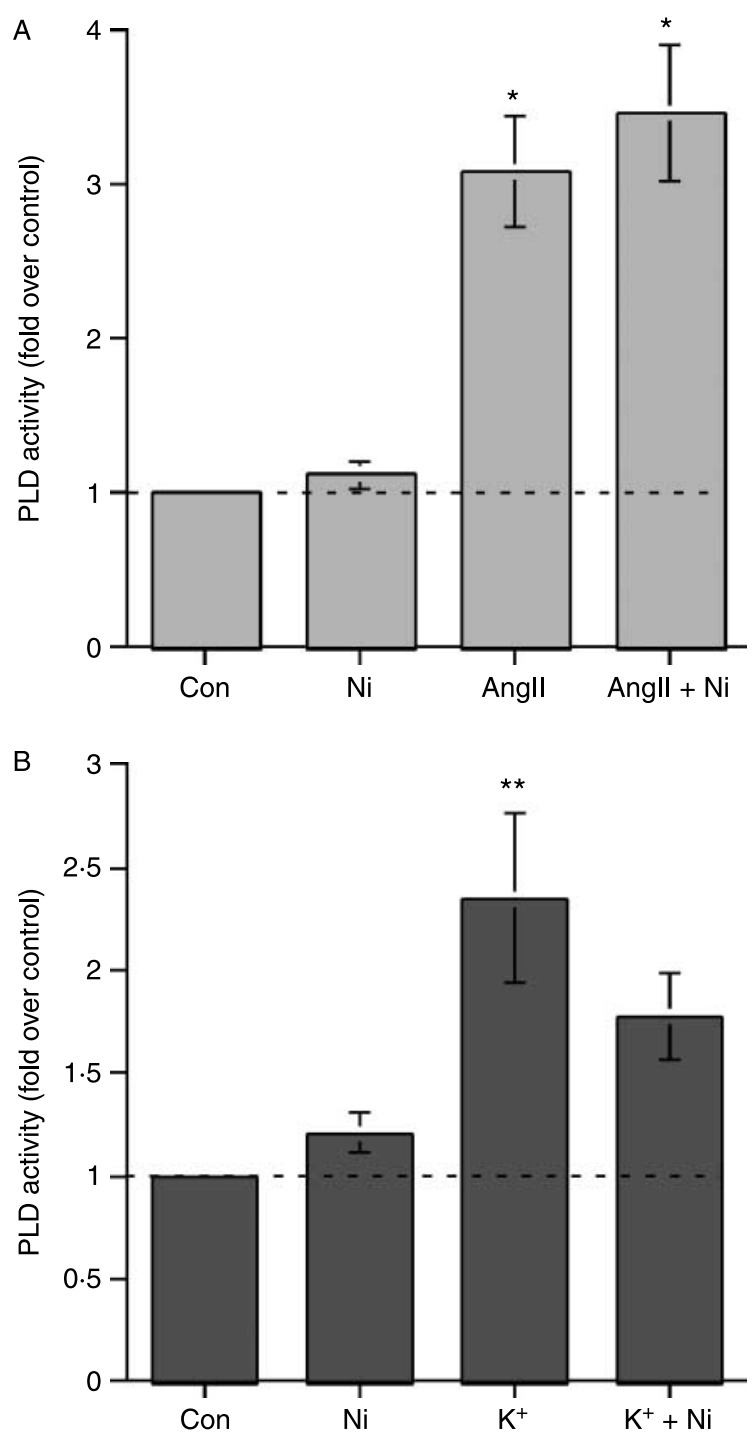

Figure 2 Inhibition of $\alpha-1 \mathrm{H}$ T-type $\mathrm{Ca}^{2+}$ channels with nickel inhibited elevated $\left[\mathrm{K}^{+}\right]_{\mathrm{e}^{-}}$, but not Angll-, elicited PLD activation. (A) $\left[{ }^{3} \mathrm{H}\right]$ Oleate-prelabeled cells were incubated for $30 \mathrm{~min}$ with $\mathrm{KRB}^{+}$containing $0 \cdot 5 \%$ ethanol and with and without $10 \mathrm{nM}$ Angll in the presence or absence of $50 \mu \mathrm{M}$ nickel (Ni) for $30 \mathrm{~min}$.

Reactions were terminated by the addition of $0 \cdot 2 \%$ SDS containing $5 \mathrm{mM}$ EDTA, and $\left[{ }^{3} \mathrm{H}\right]$ phosphatidylethanol was extracted, separated by thin-layer chromatography and quantified as in Jung et al. (1998). Values are expressed as -fold over the control and represent the means $( \pm$ S.E.M.) of four separate experiments; $* P<0 \cdot 05$ versus the control value. (B) $\left[{ }^{3} \mathrm{H}\right]$ Oleate-prelabeled cells were incubated for 30 min with $3.5 \mathrm{mM} \mathrm{K}^{+}-\mathrm{KRB}^{+}$or $15 \mathrm{mM} \mathrm{K}^{+}-\mathrm{KRB}^{+}$containing $0.5 \%$ ethanol in the absence or presence of $50 \mu \mathrm{M}$ nickel $(\mathrm{Ni})$ for $30 \mathrm{~min}$, and PLD activity monitored as above. Values are expressed as -fold over the control and represent the means ( \pm s.E.M.) of four separate experiments; ${ }^{* *} P<0 \cdot 01$ versus the control value.

To further examine the role of SOC in AngII- and elevated $\left[\mathrm{K}^{+}\right]_{\mathrm{e}}$-induced PLD activation, we treated cells with these agonists in the presence and absence of the SOC inhibitor, YM-58483, also known as BTP2. We found that BTP2 had

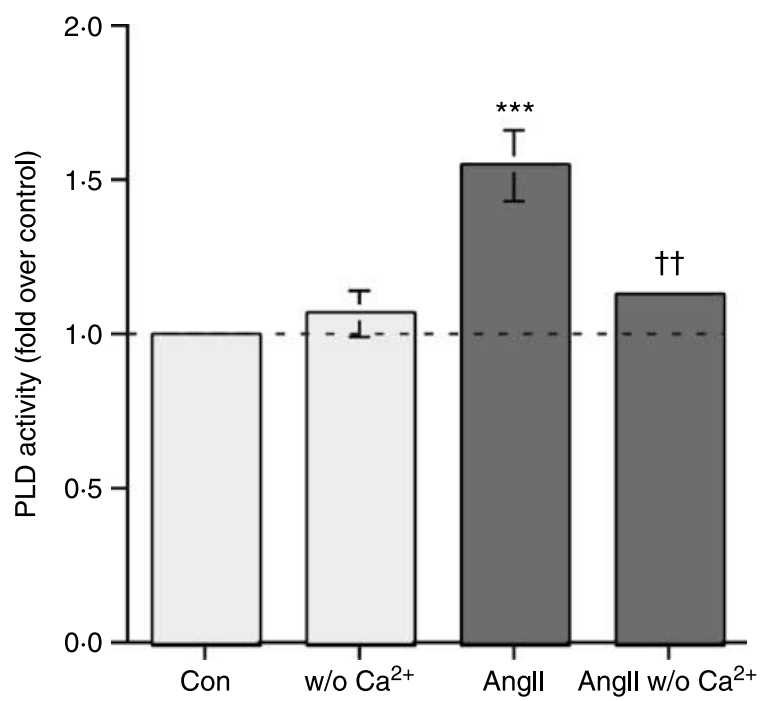

Figure 3 Angll-induced PLD activation was modulated by $\mathrm{Ca}^{2+}$ in primary bovine adrenal glomerulosa cells. Bovine adrenal glomerulosa cells were prelabeled for $20-24 \mathrm{~h}$ with $2 \cdot 5-5 \mu \mathrm{Ci} / \mathrm{ml}$ $\left[{ }^{3} \mathrm{H}\right]$ oleate in serum-free medium. Cells were then stimulated with or without $10 \mathrm{nM}$ Angll in the presence of $0.5 \%$ ethanol in medium containing $1 \cdot 2 \mathrm{mM} \mathrm{Ca}^{2+}$ or no added $\mathrm{Ca}^{2+}$ for $30 \mathrm{~min}$. Lipids were extracted and separated by thin-layer chromatography. PLD was measured as the radioactivity in phosphatidylethanol (PEt) relative to the control, and values are expressed as the means \pm S.E.M. of four separate experiments; ${ }^{* * *} P<0 \cdot 001$ versus the control value; ${ }^{++} P<0 \cdot 01$ versus the value in the presence of $\mathrm{Ca}^{2+}$.

no effect on PLD activation elicited in response to AngII (Fig. 6A). However, this agent actually seemed to increase elevated $\left[\mathrm{K}^{+}\right]_{\mathrm{e}}$-induced PLD activation, converting a nonsignificant response to elevated $\left[\mathrm{K}^{+}\right]_{\mathrm{e}}$ alone to a significant increase in the presence of BTP2 (Fig. 6B). This result suggests that whereas SOC can enhance the activation of PLD, i.e. in conjunction with elevated $\left[\mathrm{K}^{+}\right]_{\mathrm{e}}$, it is not necessary for PLD activation in response to either agonist.

The archetypical SOC pathway is CRAC, mediated by Stim and Orai proteins (reviewed in Potier \& Trebak (2008)). To examine the possible role of CRAC channels in AngIIinduced PLD activation, we determined the effect of the CRAC channel inhibitor, tyrphostin A9 (Denys et al. 2004) on this signaling event. As shown in Fig. 7A, we found that tyrphostin A9 inhibited AngII-elicited PLD activation in primary bovine adrenal glomerulosa cells, without affecting basal PLD activity. By contrast, tyrphostin A9 had no effect on elevated $\left[\mathrm{K}^{+}\right]_{\mathrm{e}}$-induced PLD activation in the primary glomerulosa cells (Fig. 7B). In experiments to determine the ability of tyrphostin A9 to modulate the aldosterone secretory response, we found that tyrphostin A9 completely blocked AngII- and elevated $\left[\mathrm{K}^{+}\right]_{\mathrm{e}}$-induced aldosterone secretion (data not shown). However, we also observed that tyrphostin A9 significantly inhibited the ability of 22(R)hydroxycholesterol to trigger steroidogenesis (Fig. 7C). Because 22(R)-hydroxycholesterol can directly enter mitochondria to access the rate-limiting enzyme of aldosterone 

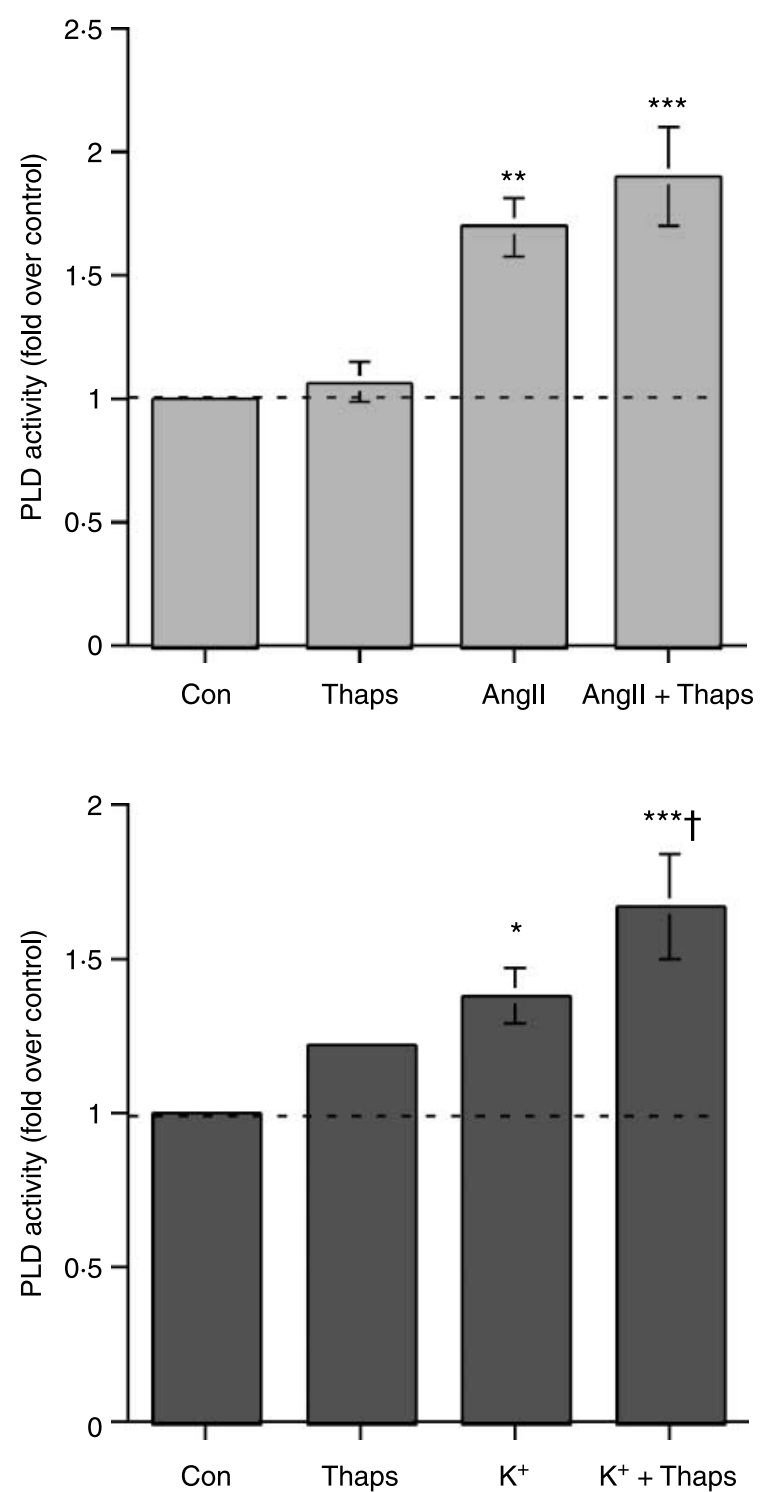

Figure 4 Thapsigargin had little or no effect on Angll-induced PLD activation, but enhanced the effect of elevated $\left[\mathrm{K}^{+}\right]_{\mathrm{e}}$ on PLD activity in bovine adrenal glomerulosa cells. (A) Bovine adrenal glomerulosa cells were prelabeled for $20-24 \mathrm{~h}$ with $2 \cdot 5-5 \mu \mathrm{Ci} / \mathrm{ml}$ $\left[{ }^{3} \mathrm{H}\right]$ oleate in serum-free medium. Cells were then stimulated with or without $10 \mathrm{nM}$ Angll in the presence or absence of $2 \mu \mathrm{M}$ thapsigargin (Thaps) or vehicle $(0 \cdot 1-0 \cdot 2 \%$ DMSO) in the presence of $0.5 \%$ ethanol for $30 \mathrm{~min}$. Lipids were extracted and separated by thin-layer chromatography. Values represent the radioactivity in phosphatidylethanol relative to the control and are expressed as the means \pm S.E.M. of nine separate experiments; $* P<0 \cdot 05$ versus the control value. (B) $\left[{ }^{3} \mathrm{H}\right]$ Oleate-prelabeled bovine adrenal glomerulosa cells were incubated with $3.5 \mathrm{mM} \mathrm{K}^{+}$ $\mathrm{KRB}^{+}$or $15 \mathrm{mM} \mathrm{K}^{+}-\mathrm{KRB}^{+}$in the presence or absence of $2 \mu \mathrm{M}$ thapsigargin (Thaps) or vehicle $(0 \cdot 1-0 \cdot 2 \%$ DMSO) in the presence of $0.5 \%$ ethanol for $30 \mathrm{~min}$. Lipids were extracted and separated by thin-layer chromatography. Values represent the radioactivity in phosphatidylethanol relative to the control and are expressed as the means \pm S.E.M. of five separate experiments; ${ }^{* *} P<0 \cdot 01$ versus the control value; ${ }^{\dagger} P<0 \cdot 05$ versus $\mathrm{K}^{+}$alone. synthesis, thereby bypassing signaling mechanisms, inhibitory effects on secretion induced by this compound indicate that tyrphostin A9 either inhibits aldosterone biosynthetic enzymes or affects cell health. However, the fact that tyrphostin A9 did not alter basal or elevated $\left[\mathrm{K}^{+}\right]_{\mathrm{e}}$-elicited PLD activity indicates that the inhibitor is not simply cytotoxic and suggests instead that the compound inhibits an enzyme in the aldosterone synthetic pathway.

We have previously shown that AngII activates PLD in H295R cells (Zheng \& Bollag 2003), as in primary cultures of bovine adrenal glomerulosa cells (Bollag et al. 1990), and that this activity mediates, at least in part, the ability of AngII to induce steroidogenesis (Zheng \& Bollag 2003), as in the bovine cells (Bollag et al. 2002). However, in contrast to results in primary bovine adrenal glomerulosa cells, in which AngII-induced PLD activation is sustained (Jung et al. 1998), in H295R cells AngII elicits only transient PLD activation (Zheng \& Bollag 2003). We wished to examine whether H295R cells exhibited other differences in the mechanism of PLD activation in response to aldosterone agonists. Initially, we examined the $\mathrm{Ca}^{2+}$ dependence of AngII-induced PLD activation in the H295R cells. Similar to the primary bovine adrenal glomerulosa cells (Fig. 2), a lack of extracellular $\mathrm{Ca}^{2+}$ also inhibited AngII-elicited PLD activation in H295R cells (Fig. 8). Importantly, however, we were unable to detect PLD activation in response to elevated $\left[\mathrm{K}^{+}\right]_{\mathrm{e}}$ in the H295R cells under a variety of conditions (data not shown), including at different time points and following pretreatment with aldosterone, reported to increase T-type channel expression (Lesouhaitier et al. 2001).

On the other hand and in contrast to the primary bovine adrenal glomerulosa cells (Fig. 4), thapsigargin enhanced AngII-induced PLD activation in the H295R cells (Fig. 9A). The effects on AngII-induced PLD activation in the H295R cells were not accompanied by comparable changes in aldosterone secretion, as thapsigargin had little or no effect on AngII-induced aldosterone production (Fig. 9B), although this result was similar to that observed in the primary bovine adrenal glomerulosa cells (Fig. 4). However, in contrast to the bovine cells, thapsigargin did not alter elevated $\left[\mathrm{K}^{+}\right]_{\mathrm{e}}$-elicited steroidogenesis in the H295R cells (Fig. 9B). Taken together, these results suggest that while similarities exist between the mechanisms of AngII-induced PLD activation in primary bovine adrenal glomerulosa cells versus the human adrenocortical carcinoma H295R cells, there are also distinct differences. However, which AngII-elicited PLD activation scenario is most similar to the situation occurring in vivo, i.e. in human patients, is at present unknown.

\section{Discussion}

We have previously shown that PLD-mediated signal generation is required for maximal AngII-induced secretion in both primary cultures of bovine adrenal glomerulosa cells and the NCI H295R human adrenocortical carcinoma cell 

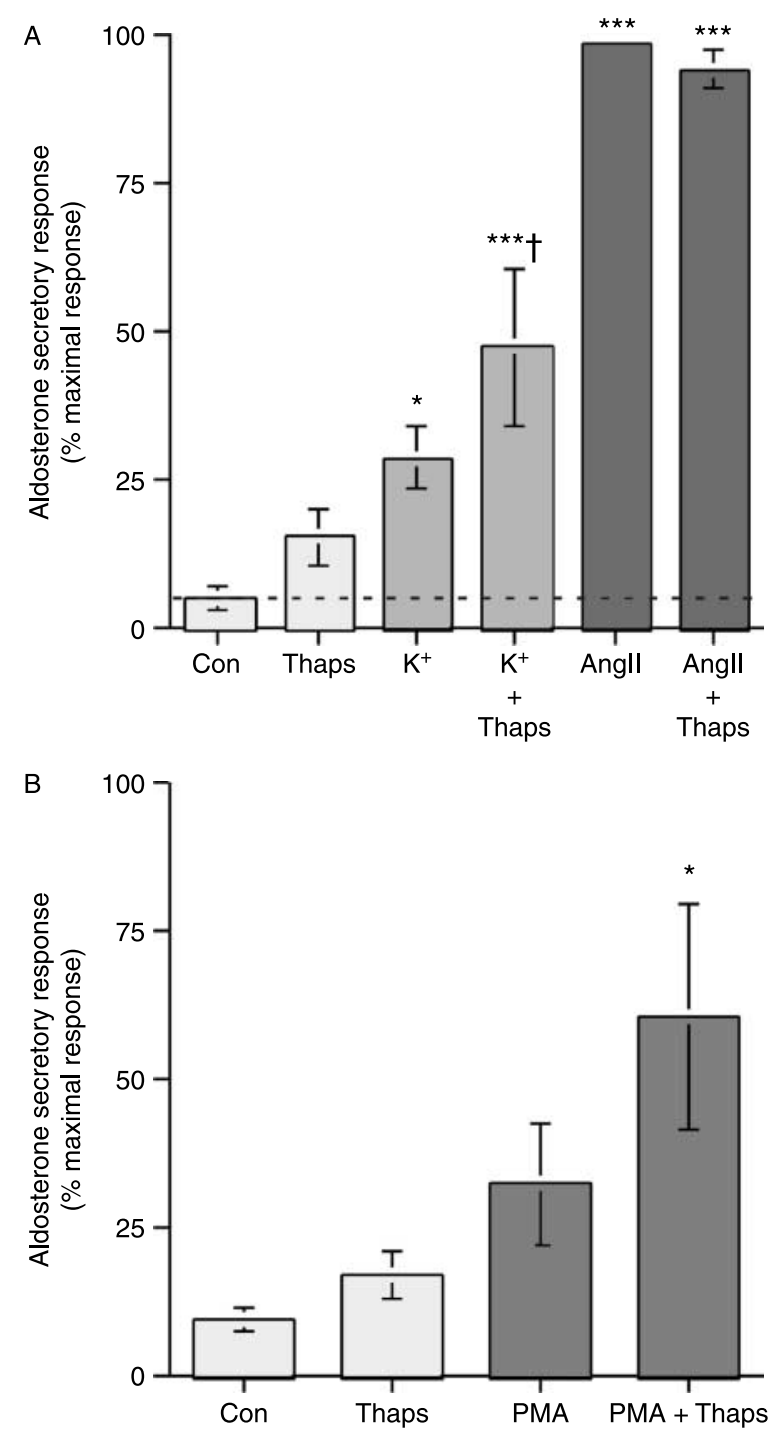

Figure 5 Thapsigargin had little or no effect alone or on Angllstimulated aldosterone secretion but enhanced steroidogenesis in response to elevated $\left[\mathrm{K}^{+}\right]_{\mathrm{e}}$ and PMA in primary cultures of bovine adrenal glomerulosa cells. (A) Bovine adrenal glomerulosa cells were incubated for $1 \mathrm{~h}$ with a bicarbonate-buffered Kreb's Ringer solution with $2.5 \mathrm{mM}$ sodium acetate $\left(\mathrm{KRB}^{+}\right)$containing no additions (Con), $15 \mathrm{mM} \mathrm{KCl}\left(\mathrm{K}^{+}\right.$; iso-osmotic substitution with $\mathrm{Na}^{+}$) or $10 \mathrm{nM}$ Angll in the presence or absence of $2 \mu \mathrm{M}$ thapsigargin (Thaps) or vehicle $(0 \cdot 1-0 \cdot 2 \%$ DMSO). Supernatants were collected and assayed for aldosterone secretion by RIA. Values represent the means \pm S.E.M. of four to five separate experiments; ${ }^{*} P<0 \cdot 05,{ }^{* *} P<0 \cdot 01$ versus control by ANOVA and a StudentNewmann-Keuls post hoc test. (B) Bovine adrenal glomerulosa cells were incubated for $1 \mathrm{~h}$ with a bicarbonate-buffered Kreb's Ringer solution with $2.5 \mathrm{mM}$ sodium acetate $\left(\mathrm{KRB}^{+}\right)$containing no additions (Con) or $100 \mathrm{nM}$ PMA in the presence or absence of $2 \mu \mathrm{M}$ thapsigargin (Thaps) or vehicle $(0 \cdot 1-0 \cdot 2 \%$ DMSO). Supernatants were collected and assayed for aldosterone secretion by RIA. Values represent the means \pm S.E.M. of four to five separate experiments, expressed as the percentage of the maximal aldosterone secretory response; ${ }^{*} P<0 \cdot 05,{ }^{*} P<0 \cdot 01$ versus control by ANOVA and a Student-Newmann-Keuls post hoc test.

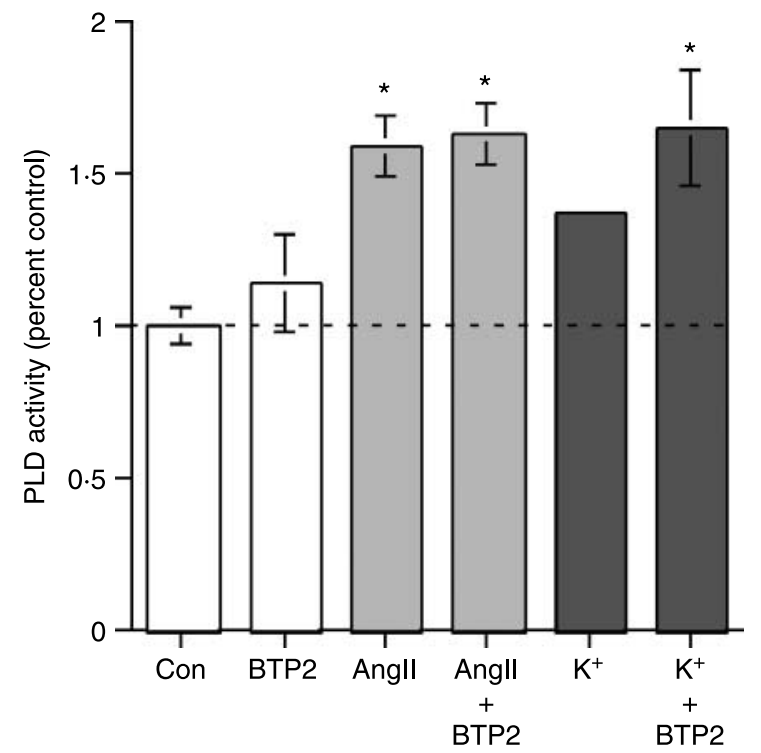

Figure 6 Inhibition of store-operated $\mathrm{Ca}^{2+}$ influx with BTP2 (YM-58483) had no effect on Angll-induced, and increased elevated $\left[\mathrm{K}^{+}\right]_{\mathrm{e}}$-elicited PLD activation. (A) $\left[{ }^{3} \mathrm{H}\right]$ Oleate-prelabeled cells were incubated for 30 min with $\mathrm{KRB}^{+}$containing $0 \cdot 5 \%$ ethanol and vehicle $(0 \cdot 1 \%$ DMSO) or $10 \mathrm{nM}$ Angll in the presence or absence of $1 \mu \mathrm{M}$ BTP2 for $30 \mathrm{~min}$. Reactions were terminated by the addition of $0 \cdot 2 \%$ SDS containing $5 \mathrm{mM}$ EDTA, and $\left[{ }^{3} \mathrm{H}\right]$ phosphatidyl-ethanol was extracted, separated by thin-layer chromatography and quantified as in Jung et al. (1998). Values are expressed as -fold over the control and represent the means ( \pm s.E.M.) of four separate experiments; $* P<0.05$ versus the control value. (B) $\left[{ }^{3} \mathrm{H}\right]$ Oleate-prelabeled cells were incubated for $30 \mathrm{~min}$ with $3.5 \mathrm{mM} \mathrm{K}^{+}-\mathrm{KRB}^{+}$or $15 \mathrm{mM} \mathrm{K}^{+}$$\mathrm{KRB}^{+}$containing $0 \cdot 5 \%$ ethanol with vehicle $(0 \cdot 1 \% \mathrm{DMSO})$ or $1 \mu \mathrm{M}$ BTP2 for $30 \mathrm{~min}$, and PLD activity monitored as above. Values are expressed as -fold over the control and represent the means ( \pm S.E.M.) of four separate experiments; ${ }^{*} P<0.05$ versus the control value.

line (Bollag et al. 2002, Zheng \& Bollag 2003; as well as elevated $\left[\mathrm{K}^{+}\right]_{\mathrm{e}}$-induced steroidogenesis in bovine cells (Betancourt-Calle et al. 2001)). Because of the importance of PLD signal generation to sustained aldosterone secretion, we sought to determine the mechanism by which AngII and elevated $\left[\mathrm{K}^{+}\right]_{\mathrm{e}}$ modulate PLD's activity. Our results indicate that $\mathrm{Ca}^{2+}$ influx through voltage-dependent $\mathrm{Ca}^{2+}$ channels is absolutely required for elevated $\left[\mathrm{K}^{+}\right]_{\mathrm{e}}$-induced PLD activation. This finding is not particularly surprising considering that elevated $\left[\mathrm{K}^{+}\right]_{\mathrm{e}}$ is thought to exert its effects on adrenal glomerulosa cells by depolarizing the cells, thereby opening voltage-dependent calcium channels (reviewed in Rainey et al. (2008)). Perhaps a bit more unexpected is the observation that AngII-induced PLD activity also requires $\mathrm{Ca}^{2+}$ influx, although this $\mathrm{Ca}^{2+}$ influx is not mediated by voltage-dependent $\mathrm{Ca}^{2+}$ channels, as neither nitrendipine nor nickel has an inhibitory effect on AngII-induced PLD activation (Bollag et al. 2002). However, removal of extracellular $\mathrm{Ca}^{2+}$ inhibits AngII-elicited PLD activation in both primary bovine adrenal glomerulosa cells (Fig. 3) and $\mathrm{H} 295 \mathrm{R}$ cells (Fig. 8), suggesting that $\mathrm{Ca}^{2+}$ influx plays some 
role in PLD activation. Nevertheless, the importance of $\mathrm{Ca}^{2+}$ in regulating PLD activity was somewhat unanticipated since we previously found no effect of $\mathrm{Ca}^{2+}$ ionophores on PLD activity in primary glomerulosa cells nor inhibition of
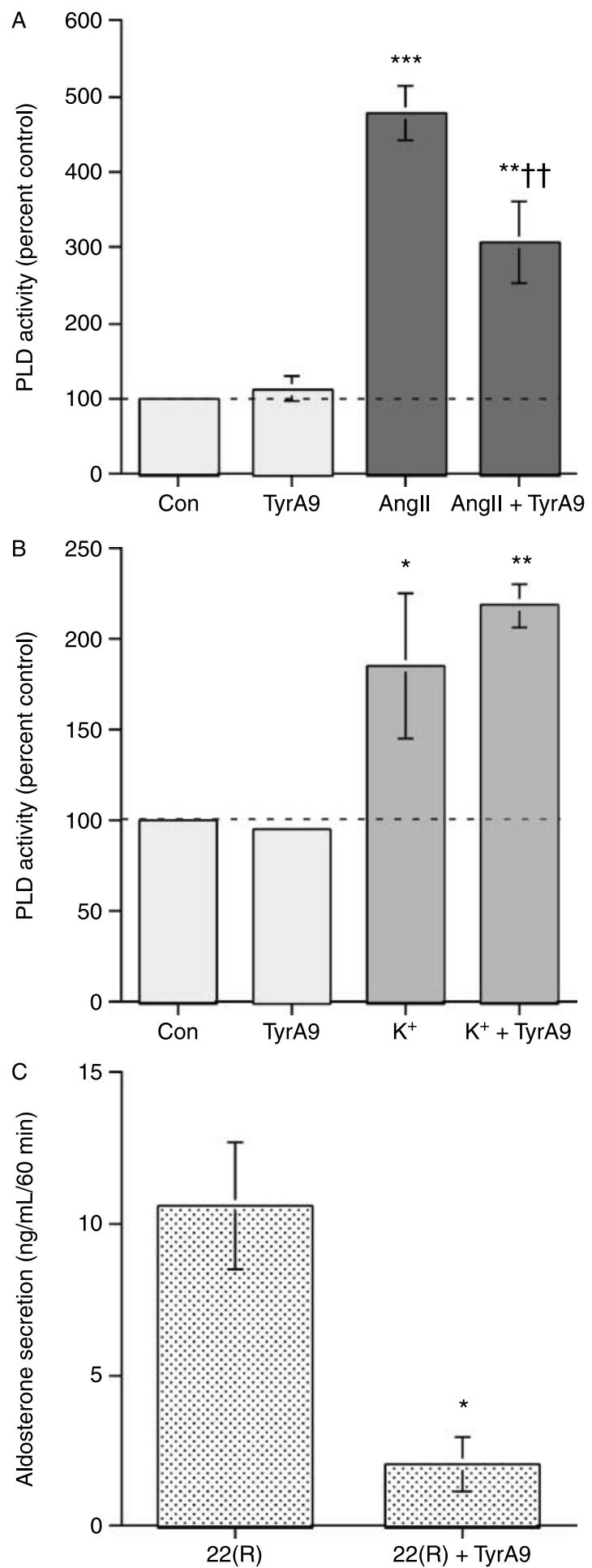

www.endocrinology-journals.org
AngII-induced enzyme activation by a voltage-dependent $\mathrm{Ca}^{2+}$ channel antagonist (Bollag et al. 2002). On the other hand, we have previously shown that in both cell models, PKC appears to mediate, at least in part, PLD activation in response to AngII (Bollag et al. 2002, Zheng \& Bollag 2003), as has been reported for other cell systems (reviewed in Frohman \& Morris (1996) and Exton (1998)). Thus, exposure to PMA is sufficient to induce PLD activation in both bovine and H295R cells (Bollag et al. 2002, Zheng \& Bollag 2003), and PKC inhibitors reduce AngII-stimulated PLD activity (Zheng \& Bollag 2003). Thus, the requirement for $\mathrm{Ca}^{2+}$ influx may be related to activation of PKC, presumably a classical, $\mathrm{Ca}^{2+}$-dependent PKC isoenzyme, as suggested by the results of Kojima et al. (1994) who demonstrated that $\mathrm{Ca}^{2+}$ can, indeed, regulate PKC activity.

Although voltage-dependent $\mathrm{Ca}^{2+}$ channels do not appear to be involved in AngII-stimulated PLD activation (Bollag et al. 2002), AngII also increases $\mathrm{Ca}^{2+}$ influx through other pathways, such as SOC and CRAC (reviewed in Spät \& Hunyady (2004)). Stimulation of SOC by thapsigargin has no effect alone or together with AngII on PLD activation in primary bovine adrenal glomerulosa cells (Fig. 3). We also observed no effect of thapsigargin on AngII-elicited aldosterone secretion, in contrast to a previous report in rat adrenal glomerulosa cells (Hajnoczky et al. 1991). The reason for this disparity is unclear but may be related to the species and/or the use of submaximal concentrations of AngII and thapsigargin in the rat cells (Hajnoczky et al. 1991). Nevertheless, the $2 \mu \mathrm{M}$ thapsigargin dose used herein was sufficient to enhance the elevated $\left[\mathrm{K}^{+}\right]_{\mathrm{e}}$-stimulated PLD

Figure 7 Inhibition of $\mathrm{Ca}^{2+}$ release-activated $\mathrm{Ca}^{2+}$ influx with tyrphostin A9 inhibited Angll-, but not elevated $\left[\mathrm{K}^{+}\right]_{\mathrm{e}^{-}}$, elicited PLD activation. (A) $\left[{ }^{3} \mathrm{H}\right]$ Oleate-prelabeled cells were incubated for 30 min with $\mathrm{KRB}^{+}$containing $0.5 \%$ ethanol and vehicle $(0 \cdot 1 \%$ DMSO, control) or $10 \mathrm{nM}$ Angll (+0.1\% DMSO) in the presence or absence of $10 \mu \mathrm{M}$ tyrphostin A9 (TyrA9) for $30 \mathrm{~min}$. Reactions were terminated by the addition of $0 \cdot 2 \%$ SDS containing $5 \mathrm{mM}$ EDTA, and $\left[{ }^{3} \mathrm{H}\right]$ phosphatidylethanol was extracted, separated by thin-layer chromatography, and quantified as in Jung et al. (1998). Values are expressed as -fold over the control and represent the means ( \pm S.E.M.) of five separate experiments; ${ }^{* *} P<0 \cdot 01,{ }^{* * *} P<0 \cdot 001$ versus the control value, ${ }^{++} P<0 \cdot 01$ versus Angll alone.

(B) $\left[{ }^{3} \mathrm{H}\right]$ Oleate-prelabeled cells were incubated for $30 \mathrm{~min}$ with $3.5 \mathrm{mM} \mathrm{K}^{+}-\mathrm{KRB}^{+}$or $15 \mathrm{mM} \mathrm{K}^{+}-\mathrm{KRB}^{+}$containing $0.5 \%$ ethanol and vehicle $(0 \cdot 1 \%$ DMSO, control) or $10 \mu \mathrm{M}$ tyrphostin A9 (TyrA9) for $30 \mathrm{~min}$, and PLD activity monitored as above. Values are expressed as -fold over the control and represent the means ( \pm S.E.M.) of four separate experiments; $* P<0 \cdot 05,{ }^{* *} P<0 \cdot 01$ versus the control value. (C) Bovine adrenal glomerulosa cells were incubated for $1 \mathrm{~h}$ with $\mathrm{KRB}^{+}$containing no additions (Con) or $10 \mu \mathrm{M} 22$ (R)-hydroxycholesterol in the presence or absence of $10 \mu \mathrm{M}$ tyrphostin A9 (TyrA9) or vehicle $(0 \cdot 1-0 \cdot 2 \%$ DMSO).

Supernatants were collected and assayed for aldosterone secretion by RIA. Values represent the means \pm s.E.M., expressed as the ng aldosterone/ml per $60 \mathrm{~min}$, of three separate experiments; ${ }^{*} P<0 \cdot 03$ versus $22(\mathrm{R})$-hydroxycholesterol alone, as determined using an unpaired Student's $t$-test. Note that 22(R)-hydroxycholesterol induced a significant, $\sim 11000$-fold increase over the control aldosterone secretory value. 


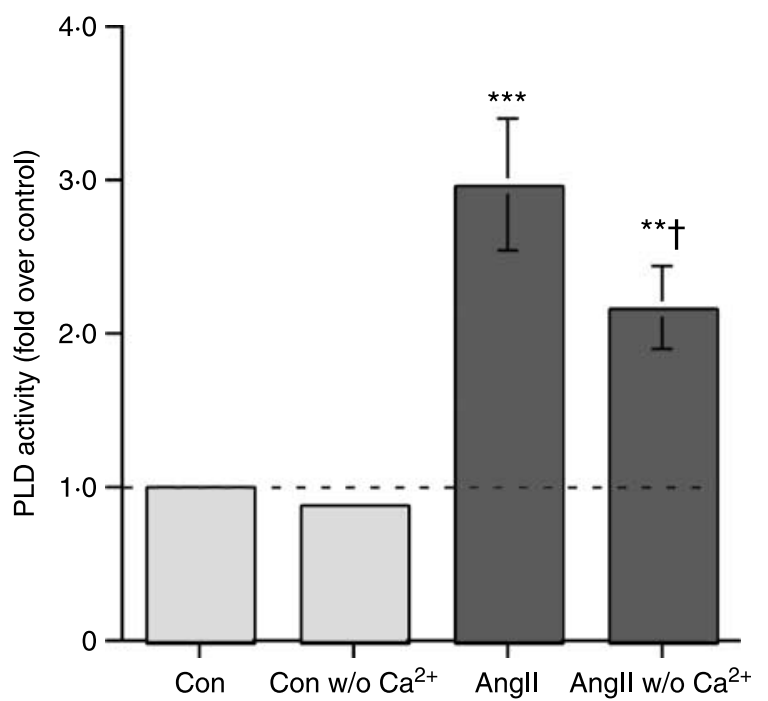

Figure 8 Angll-induced PLD activation was modulated by $\mathrm{Ca}^{2+}$ in $\mathrm{NCI} \mathrm{H295R} \mathrm{adrenocortical} \mathrm{carcinoma} \mathrm{cells.} \mathrm{H295R} \mathrm{cells} \mathrm{were}$ prelabeled for $20-24 \mathrm{~h}$ with $2 \cdot 5-5 \mu \mathrm{Ci} / \mathrm{ml}\left[{ }^{3} \mathrm{H}\right]$ oleate in serum-free medium. Cells were then stimulated with or without $100 \mathrm{nM}$ Angll in $\mathrm{KRB}^{+}$containing $1 \cdot 2 \mathrm{mM} \mathrm{Ca}^{2+}$ or no added $\mathrm{Ca}^{2+}$ in the presence of $0.5 \%$ ethanol for $5 \mathrm{~min}$. Lipids were extracted and separated by thin-layer chromatography. Values represent the radioactivity in phosphatidylethanol (PEt) relative to the control and are expressed as the means \pm S.E.M. of four separate experiments; ${ }^{* *} P<0.01,{ }^{* * *} P<0.01$ versus the control value, ${ }^{+} P<0.05$ versus the value in the presence of $\mathrm{Ca}^{2+}$.

activity and aldosterone secretory rate (Fig. 4), indicating its efficacy in promoting emptying of the intracellular $\mathrm{Ca}^{2+}$ store, as has been previously demonstrated in these same cells (Burnay et al. 1998, Aptel et al. 1999). On the other hand, however, thapsigargin was able to enhance AngII's activation of PLD in H295R cells (Fig. 9). It is not clear why there is the disparity between the two cell types, although we have previously reported that AngII induces a transient PLD activation in H295R cells (Zheng \& Bollag 2003) but a sustained activity in bovine adrenal glomerulosa cells (Jung et al. 1998). Similarly, Bird et al. (1993) have shown that the production of inositol bis- and trisphosphates in response to AngII in the H295R cells is also transient, whereas in bovine adrenal glomerulosa cells AngII elicits a sustained phosphoinositide hydrolysis response (Kojima et al. 1984). These data suggest that phosphoinositide-specific phospholipase $\mathrm{C}$ is only transiently activated in H295R cells by AngII, such that over time the endoplasmic reticulum $\mathrm{Ca}^{2+}$ pool might be expected to refill upon extinction of the transient signal, thereby terminating SOC. Thus, thapsigargin, by prolonging SOC influx could enhance PLD activation (Fig. 9A) in response to AngII in the H295R cells, without affecting these parameters in primary bovine adrenal glomerulosa cells (Fig. 5), which exhibit sustained AngII-elicited phospholipase $\mathrm{C}$ activation and therefore maintained (i.e. already maximal) SOC. However, despite its enhancement of AngII-induced PLD activation in H295R cells, thapsigargin did not alter
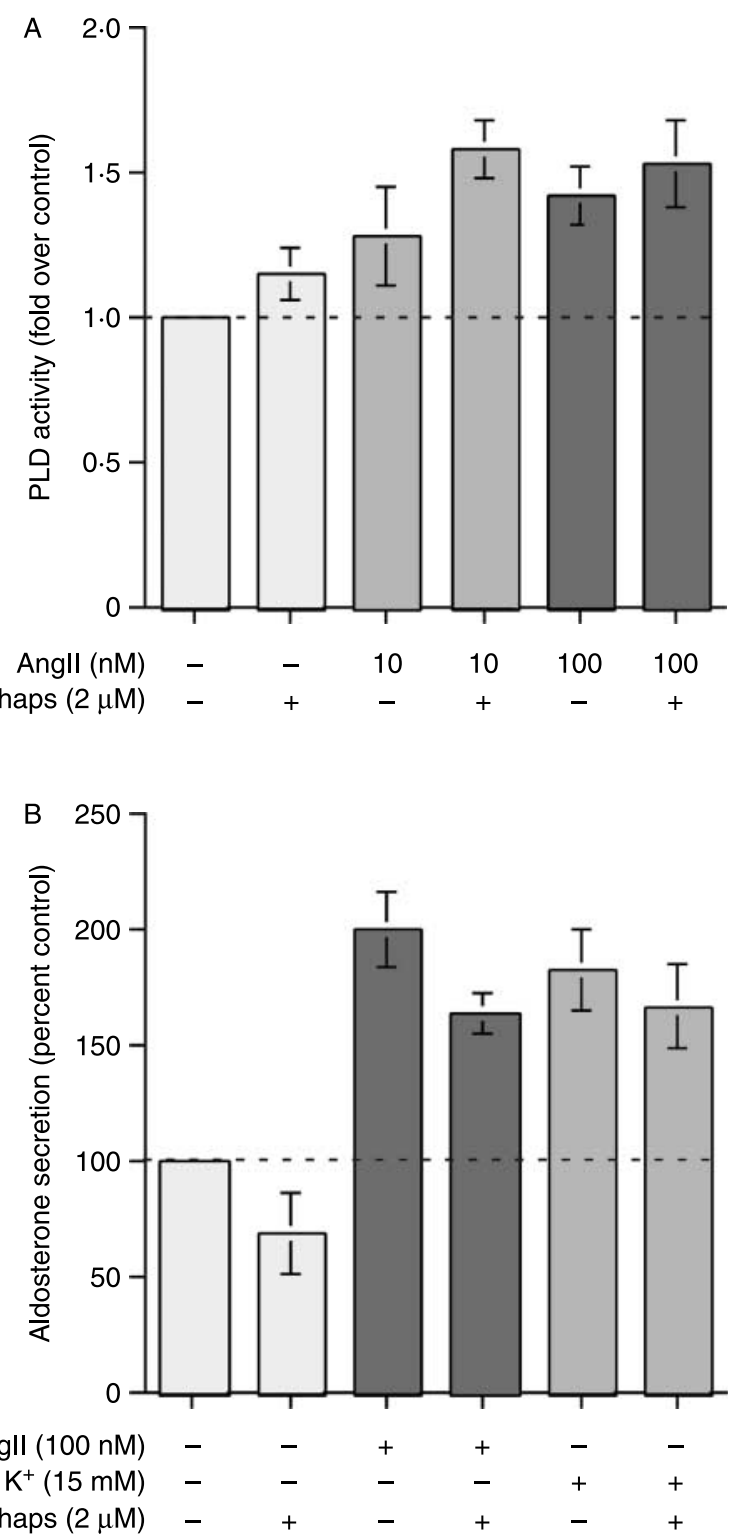

Figure 9 Thapsigargin enhanced the effect of Angll on PLD activation but had no effect on Angll- (or elevated $\left[\mathrm{K}^{+}\right]_{\mathrm{e}^{-}}$) stimulated aldosterone secretion in H295R cells. (A) H295R cells were prelabeled for $20-24 \mathrm{~h}$ with $2 \cdot 5-5 \mu \mathrm{Ci} / \mathrm{ml}\left[{ }^{3} \mathrm{H}\right]$ oleate in serum-free medium. Cells were then stimulated with or without 10 or $100 \mathrm{nM}$ Angll in the presence or absence of $2 \mu \mathrm{M}$ thapsigargin (Thaps) or vehicle $(0 \cdot 2 \%$ DMSO) in the presence of $0.5 \%$ ethanol. Lipids were extracted and separated by thin-layer chromatography. Values represent the radioactivity in phosphatidylethanol relative to the control and are expressed as the means \pm S.E.M. of three separate experiments; $* P<0.05$ versus the control value. (B) $\mathrm{H} 295 \mathrm{R}$ cells were incubated for $5 \mathrm{~h}$ with medium containing no additions (Con), $15 \mathrm{mM} \mathrm{KCl}\left(\mathrm{K}^{+}\right)$, or $100 \mathrm{nM} \mathrm{Angll}$ in the presence or absence of $2 \mu \mathrm{M}$ thapsigargin (Thaps) or vehicle $(0 \cdot 1-0 \cdot 2 \%$ DMSO) as indicated. Supernatants were collected and assayed for aldosterone secretion by RIA. Values represent the means \pm S.E.M. of four to five separate experiments; ${ }^{*} P<0 \cdot 05,{ }^{* *} P<0 \cdot 01,{ }^{* * *} P<0 \cdot 001$ versus the control value. 
AngII- (or elevated $\left[\mathrm{K}^{+}\right]_{\mathrm{e}^{-}}$) stimulated aldosterone secretion in these cells (Fig. 9B). Furthermore, the SOC inhibitor BTP2 (YM-5848) had no effect on AngII-induced PLD activation and appeared to increase that elicited by elevated $\left[\mathrm{K}^{+}\right]_{\mathrm{e}}$ (Fig. 6), suggesting that $\mathrm{Ca}^{2+}$ influx mediated by SOC is not necessary for PLD activation in response to either agonist (Fig. 6).

SOC $\mathrm{Ca}^{2+}$ influx occurs through a pathway exhibiting heterogeneous characteristics, with BTP2 reported to inhibit transient receptor potential (TRP) channels, with a halfmaximal inhibitory concentration of $0 \cdot 1-0 \cdot 3 \mu \mathrm{M}$ ( He et al. 2005). On the other hand, CRAC represents an archetypical SOC (reviewed in Potier \& Trebak (2008)). Based on our results, CRAC may be a key AngII-induced $\mathrm{Ca}^{2+}$ influx pathway involved in regulating PLD activation in primary bovine adrenal glomerulosa cells. Thus, a CRAC inhibitor, tyrphostin A9 (Denys et al. 2004), inhibited AngII-stimulated PLD activity but had no effect on the basal or elevated $\left[\mathrm{K}^{+}\right]_{\mathrm{e}^{-}}$ induced value (Fig. 7A and B). Tyrphostin A9 has also been reported to inhibit platelet-derived growth factor receptor tyrosine kinase activity (Marhaba et al. 1996); thus, the possibility remains that the effects of this compound on AngII-induced PLD activation may be related to inhibition of tyrosine kinase. However, in H295R cells, we were previously unable to detect an effect of the general tyrosine kinase inhibitor, genistein (or the Janus kinase inhibitor AG490 or Src kinase inhibitor PP2), on AngII-stimulated PLD activity (Zheng \& Bollag 2003), suggesting the likelihood that tyrphostin A9's inhibition of CRAC mediates the inhibition of PLD activation in response to AngII. Unfortunately, it was not possible to determine whether CRAC was important in AngII-elicited steroidogenesis. Although tyrphostin A9 completely inhibited AngII-induced aldosterone secretion, as well as that elicited in response to elevated $\left[\mathrm{K}^{+}\right]_{\mathrm{e}}$ (data not shown), it also inhibited secretion in response to 22(R)-hydroxycholesterol (Fig. 7C), indicating either effects on cell health or on one or more aldosterone biosynthetic enzymes. However, the inability of tyrphostin A9 to alter basal or elevated $\left[\mathrm{K}^{+}\right]_{\mathrm{e}}$-stimulated PLD activity (Fig. 6) suggests that cytotoxicity was not responsible for the inhibition. An ability of inhibitors to affect aldosterone biosynthetic enzymes is not without precedent, as Rainey et al. have demonstrated that genistein inhibits $3 \beta$-hydroxysteroid dehydrogenase (Sirianni et al. 2001).

As expected, in primary bovine adrenal glomerulosa cells, elevated $\left[\mathrm{K}^{+}\right]_{\mathrm{e}}$-induced PLD activation was dependent on voltage-dependent $\mathrm{Ca}^{2+}$ channels (Fig. 1). Interestingly, SOC also appeared to stimulate elevated $\left[\mathrm{K}^{+}\right]_{\mathrm{e}}$-elicited PLD activation and aldosterone secretion in bovine adrenal glomerulosa cells, as shown by the ability of thapsigargin to stimulate these processes (Figs 4 and 5). There is some controversy as to whether elevated $\left[\mathrm{K}^{+}\right]_{\mathrm{e}}$ triggers phosphoinositide hydrolysis (Hunyady et al. 1982, Kojima et al. 1985a, Underwood et al. 1988, Ganguly et al. 1990, Hajnoczky et al. 1992, Betancourt-Calle et al. 2001). Our data, however, would suggest that if it does so, elevated $\left[\mathrm{K}^{+}\right]_{\mathrm{e}}$ is not particularly effective at inducing SOC, since thapsigargin can augment the effects of this ion on aldosterone secretion in primary bovine adrenal glomerulosa (Fig. 5). On the other hand, we were unable to detect elevated $\left[\mathrm{K}^{+}\right]_{\mathrm{e}}$-induced PLD activation in H295R cells, under a variety of conditions (data not shown), suggesting differences in signal transduction, particularly with regards to the $\mathrm{Ca}^{2+}$ signal, in the bovine adrenal glomerulosa cells versus the H295R cells.

Together, our results suggest that: 1) PLD activation in response to elevated $\left[\mathrm{K}^{+}\right]_{\mathrm{e}}$, but not AngII, is dependent on $\mathrm{Ca}^{2+}$ influx via voltage-dependent $\mathrm{Ca}^{2+}$ channels, but 2) AngII-induced PLD activation nevertheless requires $\mathrm{Ca}^{2+}$, likely entering the cell through CRAC channels. Furthermore, our results highlight the importance of the specific $\mathrm{Ca}^{2+}$ influx pathway in coupling of the aldosterone agonists, AngII and elevated $\left[\mathrm{K}^{+}\right]_{\mathrm{e}}$ to PLD activation in adrenal glomerulosa cells.

\section{Declaration of interest}

The authors declare that there is no conflict of interest that could be perceived as prejudicing the impartiality of the research reported.

\section{Funding}

This work was supported by a National Institutes of Health Award \#HL7 0046 and American Heart Association Grant-in-Aid Award \#0350166N.

\section{References}

Aptel HB, Burnay MM, Rossier MF \& Capponi AM 1999 The role of tyrosine kinases in capacitative calcium influx-mediated aldosterone production in bovine adrenal zona glomerulosa cells. Journal of Endocrinology 163 131-138.

Barrett PQ, Bollag WB, Isales CM, McCarthy RT \& Rasmussen H 1989 Role of calcium in angiotensin II-mediated aldosterone secretion. Endocrine Reviews $101-22$.

Barrett PQ, Ertel EA, Smith MM, Nee JJ \& Cohen CJ 1995 Voltage-gated calcium currents have two opposing effects on the secretion of aldosterone. American Journal of Physiology 268 C985-C992.

Betancourt-Calle S, Jung EM, White S, Calle RA, Rasmussen H \& Bollag WB 2001 Elevated $\mathrm{K}^{+}$induces MARCKS phosphorylation and phospholipase D activation in glomerulosa cells. Molecular and Cellular Endocrinology 184 65-76.

Bird IM, Hanley NA, Word RA, Mathis JM, McCarthy JL, Mason JI \& Rainey WE 1993 Human NCI-H295 adrenocortical carcinoma cells: a model for angiotensin-II-responsive aldosterone secretion. Endocrinology 133 1555-1561.

Bollag WB 1998 Measurement of phospholipase D activity. Methods in Molecular Biology 105 151-160.

Bollag WB \& Zheng X 2005 The role of phospholipase D in keratinocyte biology. In Trends in Protein Research. Hauppauge, New York: NovaScience Publishers.

Bollag WB, Barrett PQ, Isales CM, Liscovitch M \& Rasmussen H 1990 A potential role for phospholipase-D in the angiotensin-II-induced stimulation of aldosterone secretion from bovine adrenal glomerulosa cells. Endocrinology 127 1436-1443. 
Bollag WB, Barrett PQ, Isales CM, Liscovitch M \& Rasmussen H 1992 Signal transduction mechanisms involved in carbachol-induced aldosterone secretion from bovine adrenal glomerulosa cells. Molecular and Cellular Endocrinology 86 93-101.

Bollag WB, Jung EM \& Calle RA 2002 Mechanism of angiotensin II-induced phospholipase D activation in adrenal glomerulosa cells. Molecular and Cellular Endocrinology 192 7-16.

Bollag WB, Kent P, White S, Malinova M, Isales CM \& Calle RA 2007 Characterization and phospholipase D mediation of the angiotensin II priming response in adrenal glomerulosa cells. Endocrinology 148 585-593.

Burnay MM, Python CP, Vallotton MB, Capponi AM \& Rossier MF 1994 Role of the capacitative calcium influx in the activation of steroidogenesis by angiotensin-II in adrenal glomerulosa cells. Endocrinology 135 751-758.

Burnay MM, Vallotton MB, Capponi AM \& Rossier MF 1998 Angiotensin II potentiates adrenocorticotropic hormone-induced cAMP formation in bovine adrenal glomerulosa cells through a capacitative calcium influx. Biochemical Journal 330 21-27.

Denys A, Aires V, Hichami A \& Khan NA 2004 Thapsigargin-stimulated MAP kinase phosphorylation via CRAC channels and PLD activation: inhibitory action of docosahexaenoic acid. FEBS Letters 564 177-182.

Exton JH 1998 Phospholipase D. Biochimica et Biophysica Acta 1436 105-115.

Exton JH 1999 Regulation of phospholipase D. Biochimica et Biophysica Acta 1439 121-133.

Foster RH 2004 Reciprocal influences between the signalling pathways regulating proliferation and steroidogenesis in adrenal glomerulosa cells. Journal of Molecular Endocrinology 32 893-902.

Frohman MA \& Morris AJ 1996 Phospholipid signalling: rho is only ARF the story. Current Biology 6 945-947.

Ganguly A, Chiou S \& Davis JS 1990 Intracellular mediators of potassiuminduced aldosterone secretion. Life Sciences 46 173-180.

Hajnoczky G, Varnai P, Hollo Z, Christensen SB, Balla T, Enyedi P \& Spat A 1991 Thapsigargin-induced increase in cytoplasmic $\mathrm{Ca}^{2+}$ concentration and aldosterone production in rat adrenal glomerulosa cells: interaction with potassium and angiotensin-II. Endocrinology 128 2639-2644.

Hajnoczky G, Varnai P, Buday L, Farago A \& Spat A 1992 The role of protein kinase-C in control of aldosterone production by rat adrenal glomerulosa cells: activation of protein kinase-C by stimulation with potassium. Endocrinology 130 2230-2236.

He LP, Hewavitharana T, Soboloff J, Spassova MA \& Gill DL 2005 A functional link between store-operated and TRPC channels revealed by the 3,4-bis(trifluoromethyl)pyrazole derivative, BTP2. Journal of Biological Chemistry 280 10997-11006.

Hunyady L, Balla T, Nagy K \& Spät A 1982 Control of phosphatidylinositol turnover in adrenal glomerulosa cells. Biochimica et Biophysica Acta $\mathbf{7 1 3}$ 352-357.

Jung EM, Betancourt-Calle S, Mann-Blakeney R, Foushee T, Isales CM \& Bollag WB 1998 Sustained phospholipase D activation in response to angiotensin II but not carbachol in bovine adrenal glomerulosa cells. Biochemical Journal 330 445-451.

Kojima I, Kojima K, Kreutter D \& Rasmussen H 1984 The temporal integration of the aldosterone secretory response to angiotensin occurs via two intracellular pathways. Journal of Biological Chemistry 259 14448-14457.
Kojima I, Kojima K \& Rasmussen H 1985a Intracellular calcium and adenosine $3^{\prime}, 5^{\prime}$-cyclic monophosphate as mediators of potassium-induced aldosterone secretion. Biochemical Journal 228 69-76.

Kojima I, Kojima K \& Rasmussen H 1985 b Role of calcium fluxes in the sustained phase of angiotensin II-mediated aldosterone secretion from adrenal glomerulosa cells. Journal of Biological Chemistry 260 9177-9184.

Kojima I, Kawamura N \& Shibata H 1994 Rate of calcium entry determines the rapid changes in protein kinase $\mathrm{C}$ activity in angiotensin II-stimulated adrenal glomerulosa cells. Biochemical Journal 297 523-528.

Lesouhaitier O, Chiappe A \& Rossier MF 2001 Aldosterone increases T-type calcium currents in human adrenocarcinoma (H295R) cells by inducing channel expression. Endocrinology 142 4320-4330.

Marhaba R, Mary F, Pelassy C, Stanescu AT, Aussel C \& Breittmayer JP 1996 Tyrphostin A9 inhibits calcium release-dependent phosphorylations and calcium entry via calcium release-activated channel in Jurkat $\mathrm{T}$ cells. Journal of Immunology 157 1468-1473.

Potier M \& Trebak M 2008 New developments in the signaling mechanisms of the store-operated calcium entry pathway. Pflügers Archiv 457 405-415.

Rainey WE, Bollag WB \& Isales CM 2008 Aldosterone regulation. In Textbook of Nephro-Endocrinology, Eds AJ Singh \& GH Williams. Atlanta, GA: Elsevier, Inc.

Rasmussen H, Isales CM, Calle R, Throckmorton D, Anderson M, Gasalla-Herraiz J \& McCarthy R 1995 Diacylglycerol production, $\mathrm{Ca}^{2+}$ influx, and protein kinase $\mathrm{C}$ activation in sustained cellular responses. Endocrine Reviews 16 649-681.

Schrier AD, Wang H, Talley EM, Perez-Reyes E \& Barrett PQ 2001 Alpha1H T-type $\mathrm{Ca}^{2+}$ channel is the predominant subtype expressed in bovine and rat zona glomerulosa. American Journal of Physiology. Cell Physiology 280 C265-C272.

Sirianni R, Sirianni R, Carr BR, Pezzi V \& Rainey WE 2001 A role for src tyrosine kinase in regulating adrenal aldosterone secretion. Journal of Molecular Endocrinology 26 207-215.

Spät A \& Hunyady L 2004 Control of aldosterone secretion: a model for convergence in cellular signaling pathways. Physiological Reviews $\mathbf{8 4}$ 489-539.

Thompson NT, Bonser RW \& Garland LG 1991 Receptor-coupled phospholipase D and its inhibition. Trends in Pharmacological Sciences 12 404-408.

Underwood RH, Greeley R, Glennon ET, Menachery AI, Braley LM \& Williams GH 1988 Mass determination of polyphosphoinositides and inositol triphosphate in rat adrenal glomerulosa cells with a microspectrophotometric method. Endocrinology 123 211-219.

Zheng X \& Bollag WB 2003 AngII induces transient phospholipase D activity in the H295R glomerulosa cell model. Molecular and Cellular Endocrinology 206 113-122.

Received in final form 22 March 2009

Accepted 15 April 2009

Made available online as an Accepted Preprint 16 April 2009 